\title{
Investigating Effects of Vitamin D Injection during a Course of Endurance Training On Anthropometrical Parameters of Wistar Rats with High-Fat Diet- Induced Obesity
}

Seyed Javad Mirghani (PhD) Department of Exercise Physiology, Faculty of Physical Education and Sports Science, Islamic Azad University, Central Tehran Branch, Tehran, Iran

Mohammad Ali Azarbayjani (PhD) Department of Exercise Physiology, Faculty of Physical Education and Sports Science, Islamic Azad University, Central Tehran Branch, Tehran, Iran

Maghsoud Peeri (PhD)

Department of Exercise Physiology, Faculty of Physical Education and Sports Science, Islamic Azad University, Central Tehran Branch, Tehran, Iran

Zahra Eslami (MSc Candidate) Department of Clinical Biochemistry, Faculty of Medicine, Golestan University of Medical Sciences, Gorgan, Iran

Abbasali Keshtkar (PhD)

Department of Health Sciences Education Development, School of Public Health, Tehran University of Medical Sciences, Tehran, Iran

Corresponding author: Seyed Javad Mirghani

Email:

seyedgavadmirghani@yahoo.com

Tel: +989120747177

Address: 16 metri Shariati, Azadegan Street, Manoochehri Avenue, Aliabade- Katoul, Golestan Province, Iran

Received: 10 Sep 2018

Revised: 20 Sep 2019

Accepted: 28 Sep 2019

\section{(c) (i) (3)}

This work is licensed under a Creative Commons Attribution 4.0 License.

\section{ABSTRACT}

Background and Objectives: The purpose of this research was to determine effects of vitamin D supplementation during a course of endurance training on anthropometrical parameters of Wistar rats exposed to a high-fat diet.

Methods: In this experimental study, 30 Wistar rats aged 5-6 weeks were assigned to five groups: 1. Control with normal diet $(\mathrm{n}=5), 2$. Control with high-fat diet $(\mathrm{n}=5)$, 3. High-fat diet and vitamin D supplementation $(\mathrm{n}=10)$, 4 . High-fat diet and endurance training $(\mathrm{n}=10)$, and 5. High-fat diet, endurance training and vitamin I supplementation $(\mathrm{n}=10)$. The animals were subjected to a high-fat diet (40\%) for 13 weeks, followed by 12 weeks of exercise and vitamin I) supplementation.

Results: Weight $(\mathrm{P}=0.02)$, BMI $(\mathrm{P}=0.001)$, Lee index $(\mathrm{P}=0.01)$ and energy efficiency $(\mathrm{P}=0.001)$ differed significantly between groups 1 and 2 . Feed efficiency $(\mathrm{P}=0.03)$ and energy efficiency $(\mathrm{P}=0.01)$ of groups 2,3 and 4 were significantly different from that of the control group.

Conclusion: The results of the present study indicate that endurance training and vitamin D) supplementation could significantly decrease some anthropometric indices.

Keywords: Endurance Training, Vitamin D, High Fat Diet, Anthropometric Indices.

This paper should be cited as: Mirghani SJ, Keshtkar A, Peeri M, Eslami Z, Azarbayjani MA.[ Investigating Effects of Vitamin D Injection during a Course of Endurance Training On Anthropometrical Parameters of Wistar Rats with High-Fat Diet-Induced Obesity]. mljgoums. 2019; 13(6): 36-43 


\section{INTRODUCTION}

Over weightiness and obesity are serious health matters throughout the world. According to WHO released in 2015, approximately 2.3 billion people over the age of 15 suffer from over weightiness and 700 million adults are fat (1). Studies shows that obese individuals are at 20 to 80 percent higher risk of affliction to cardiovascular disease, diabetes, cerebrovascular accidents and sudden death $(2,3)$. Therefore, more research about how to control weight increases and factors associated with it to prevent the incidents of obesity and reduce the number of diseases associated with it is needed.

The result of some studies indicates that vitamin D plays a significant role in secretion and sensitivity to insulin, treatment of diabetes type 2, glucose intolerance, hyperinsulinemia and obesity (4). In addition, metanalysis review results indicate that the increase in vitamin $\mathrm{D}$ level of blood serum is associated with a 43 percent decrease in cardiovascular and metabolic diseases (5). A low level of vitamin $\mathrm{D}$ in the obese individual may cause this condition $(6,7)$.

However, the new evidence shows the inadequacy of physical activity or sedentary lifestyle as the more important factor (6). There is no convincing evidence that fat content in diet is the causing of diseases such as strokes, inflammation, total mass and harmful cholesterol (7), body composition and consumed calories and absorption (8).

In regard to the problem of obesity and its prevention, physical activity has a significant role (9), weight reduction and body fat and hyperglycemia control in human and animal models have been confirmed by scientists as an effective means $(10,11)$. The reduction of weight and visceral fat (12), a decrease of food absorption in rats by manipulating diet and reducing fat mass in the animal model (13), a decrease of obesity effect in high-fat diet (14) as the result of participation in physical activity has been confirmed. For instance, endurance physical activity has always been an effective strategy to reduce weight and fat mass. The result of studies indicates that aerobic exercises have been proposed as a non-drug method for the treatment of obesity and related diseases $(15,16)$.

Shen and associates (2015) demonstrated that intensive endurance exercise resulted in a decrease In fat mass, decrease in weight increase in the high-fat content diet (17). Another research result showed that consuming fruit and vegetables and dairy product rich in vitamin $D$ results in a decrease in cardiovascular and metabolic impairment (3).

Vitamin D deficiency may have an undesirable effect on other functions of the body in addition to the skeletal system; on the other hand, the effect of injection of vitamin $D$ on morphology alteration has not been studied. Therefore, this research was designed to determine the interaction effect of vitamin D in a high-fat diet following an endurance exercise on anthropometric indices of Win star rats. Considering the scarcity of research in this regard, endurance exercise and vitamin D supplementation may have a synergic effect different than the introduction of each factor separately on anthropometric indices when a high-fat diet is adopted.

\section{MATERIALS AND METHODS}

Thirty-eight-Wistar rats were purchased from the Shahid Mirghani Research institute. This study has been reviewed in the research ethics committee of the sports science research institute and was approved with the code IR.SSRI.REC.1395.115. These animals were kept in lab conditions including 12 hours daynight cycle and a mean temperature of $22 \pm 3^{\circ} \mathrm{C}$. This research was conducted in two stages: first, 13 weeks of the fattening stage; second, 12 weeks of endurance exercise. For the purpose of adaptation with the environment, all the animals with the mean age of 5-6 weeks old and weight of 128.32 grams were divided into five groups: (1) control with normal diet $(\mathrm{n}=5)$, (2) control with high-fat-diet $(n=5), \quad(3)$ high-fat-diet and vitamin D injection $(n=10)$ (4) high-fat-diet and endurance exercise $(n=10)$, (5) high-fatdiet, endurance exercise and vitamin $\mathrm{D}$ injection $(\mathrm{n}=10)$. The research project was approved by the ethics committee of the Sport Sciences Center of Iran. General characteristic of the rats has shown in table 1 .

The full details of the methodology of this study are presented in full (18). The exercise program was performed on a rodent treadmill. The rats in the exercise conditions were placed on a one-week adaptation to the exercise program in which every animal ran on the treadmill with different speeds of 6-8-10 
meters per minute. In order to determine the maximum speed of running for every rat, the Vmax was used (19). According to this criterion, the maximum speed per rat up to the point of exhaustion was determined. Since the rats were fat, the treadmill slope was set to zero throughout the protocol. After determining the maximum speed up to the point of exhaustion (the agreed speed on this research protocol), two days of rest interval was introduced when the mean speed was calculated and individual exercise program per rat was obtained. Then, the animals started the moderate-intensity training (MIT) with the $60 \%-65 \% \mathrm{~V}$ max that is equal to the speed of 20 meters per minute and the meantime of 15:21 minutes in the first week. Gradually, the speed was increased to $25 \mathrm{~m} / \mathrm{min}$ and 31 minutes running time in the $12^{\text {th }}$ week. The start of every session included 3 minutes of warm-up at $10 \mathrm{~m} / \mathrm{min}$ followed by 2 minutes of running at the speed of $15 \mathrm{~m} / \mathrm{min}$. the cool down period included 1 minute of running at $15 \mathrm{~m} / \mathrm{min}$ speed followed by 2 minutes of running $10 \mathrm{~m} / \mathrm{min}$. The exercise program was performed 5 times per week with two days of rest interval for 12 weeks.

Body length was measured from the tip of nose to the rectum in centimeter by flexible tap, Lee index was calculated by obtaining the ratio of nose to rectum to the cubic root of weight (gr.). The calorie expenditure, the amount of food consumed to the weight gain (gr.) as the efficiency of consumed food and the ratio of weight to total calorie expenditure as the energetic was calculated for per rat during the 13 weeks of diet and 12 weeks of exercise in 4 different stages: 1 , prior to the start of interventions; 2, following the 13 weeks of diets; 3 , after 6 weeks of $40 \%$ highfat-diet and endurance exercise ; 4, after two weeks of endurance exercise and $40 \%$ highfat-diet and vitamin $\mathrm{D}$ injection. The characteristic of animals is presented in table 1.

The components of the high-fat-diet included $40 \%$ fat, (20\% soya bean oil, $20 \%$ animal fat), $14.1 \%$ protein, $36.58 \%$ carbohydrate, $8.4 \%$ mitral, and $0.72 \%$ vitamin (18).

Statistical tests including analysis of variance repeated measure were employed to test the hypothesis of interest. SPSS: pc 16 was used to perform the analysis. Shapiro-Wilk test was applied to test the normality of data and the Tukey post hoc test was used to locate the differences. All hypotheses were tested at the significant level set to 0.05 .

\section{RESULTS}

The result of an analysis indicated that there were significant differences between the group 1 and 2 in weight(p=0.02), BMI (0.001), Lee index $(\mathrm{p}=0.01)$ and energy efficiency $(\mathrm{p}=0.001)$ and between group 4 and group 2 $(\mathrm{p}<0.05)$. In addition, there were significant differences between groups 2 and 3 compared to group 1 in Lee index $(p=0.002)$ and between the Feed efficiency $(\mathrm{p}=0.03)$ and Energy Efficiency (0.01) of group 2, 3, and 4 compared to group control.

There were also significant differences between the Lee index of groups 4, and 5 compared to group $3(\mathrm{p}=0.03)$ and Energy Efficiency $(\mathrm{p}=0.001)($ Table 2$)$.

The result of analysis also showed that there was a significant difference of the groups in weight $(p=0.04)$ in stage 4 and between the four stages of the protocol $(\mathrm{p}<0.05)$, while, there were not significantly different in the fourth stage compared with the third stage in groups $1,2,3(\mathrm{p}=0.06)$ and also, the first stage compares with the second stage in group $4(\mathrm{p}=0.28)$.

There were also significant differences among the groups in BMI of stage $4(\mathrm{p}=0.001)$ and 3 $(\mathrm{p}=0.04)$ while, there was a significant difference in BMI of all groups at all stages $(\mathrm{p}=0.001$. In this regard, there were no significant differences between groups 1 and 5 in the fourth stage compared to the 3rd stage ( $p>0.05)$. In addition, in the third stage, in group 1, the fourth stage in group 2, the third and fourth stage in group 5, no significant difference was found when they were compared to the second stage $(\mathrm{p}>0.05)$ (Table $3)$.

In regard to the Lee index, there was a significant difference between the index in fourth $(\mathrm{p}=0.001)$ and the second stage $(p=0.002)$. While there was a significant difference between the index in every 4 stages $(\mathrm{p}=0.001)$, however, there was no significant difference between the Lee index in fourth and fifth stage in group 4 and 5 compared to the third stage, fourth and third stage in group 1, third stage in group 3 in contrast with the second stage $(p>0.05)$. Also, there was no significant difference among the fourth, third and second stage in contrast to the first stage (p>0.05) (table 3). 
Table1- Specifications of rats at the beginning of the study

\begin{tabular}{|c|c|c|c|c|c|c|}
\hline $\begin{array}{l}\text { Groups } \\
\text { Variables }\end{array}$ & $\begin{array}{l}\text { Control group } \\
\text { (standard diet) }\end{array}$ & $\begin{array}{l}\text { Control group } \\
\text { (High fat diet) }\end{array}$ & $\begin{array}{l}\text { Vitamin D \& } \\
\text { High fat diet }\end{array}$ & $\begin{array}{c}\text { Endurance } \\
\text { training \& High } \\
\text { fat diet }\end{array}$ & $\begin{array}{c}\text { Endurance } \\
\text { training / Vitamin } \\
\text { D\& High Fat diet }\end{array}$ & P.value \\
\hline Weight(gr) & $134.64 \pm 22.74$ & $133.33 \pm 23.34$ & $131.78 \pm 25.69$ & $128.79 \pm 27.46$ & $120.09 \pm 19.15$ & 0.98 \\
\hline Height (cm) & $17.90 \pm 1.59$ & $17.37 \pm 2.17$ & $18.20 \pm 1.89$ & $18.20 \pm 2.16$ & $16.67 \pm 1.74$ & 0.55 \\
\hline BMI & $0.41 \pm 0.08$ & $0.42 \pm 0.17$ & $0.39 \pm 0.03$ & $0.37 \pm \mathbf{0 . 1 0}$ & $0.43 \pm 0.08$ & 0.76 \\
\hline LEE & $0.28 \pm 0.01$ & $0.28 \pm 0.03$ & $0.27 \pm 0.01$ & $0.27 \pm 0.02$ & $0.25 \pm 0.01$ & 0.16 \\
\hline
\end{tabular}

Table 2- Specifications of rats at the end of the study

\begin{tabular}{|c|c|c|c|c|c|c|}
\hline Variables & $\begin{array}{c}\text { Control group } \\
\text { (standard diet) } \\
\text { Group-1 }\end{array}$ & $\begin{array}{c}\text { Control group } \\
\text { (High-fat diet) } \\
\text { Group-2 }\end{array}$ & $\begin{array}{c}\text { Vitamin D \& High- } \\
\text { fat diet } \\
\text { Group-3 }\end{array}$ & $\begin{array}{c}\text { Endurance } \\
\text { training \& High } \\
\text { fat diet } \\
\text { Group-4 }\end{array}$ & $\begin{array}{c}\text { Endurance training } \\
\text { /Vitamin D\& High } \\
\text { Fat diet } \\
\text { Group-5 }\end{array}$ & P.value \\
\hline Weight(gr) & $386.05 \pm 15.36$ & $438.55 \pm 25.34$ & $411.87 \pm 17.67$ & $391.15 \pm 33.97$ & $351.19 \pm 26.65^{a}$ & 0.02 \\
\hline Height (cm) & $24.10 \pm 0.30$ & $23.20 \pm 1.58$ & $23.00 \pm 0.58$ & $23.10 \pm 0.95$ & $22.84 \pm 1.41$ & 0.28 \\
\hline BMI & $0.68 \pm 0.04$ & $0.78 \pm 0.04^{b}$ & $0.80 \pm 0.02^{b}$ & $0.72 \pm 0.05$ & $0.51 \pm 0.01^{\mathrm{a}}$ & $<0.001$ \\
\hline LEE Index & $0.30 \pm 0.005$ & $0.32 \pm 0.013^{b}$ & $0.32 \pm 0.005^{b}$ & $0.31 \pm 0.005^{b, c}$ & $0.30 \pm 0.009^{\mathrm{a}, \mathrm{c}}$ & 0.01 \\
\hline Feed efficiency & $0.07 \pm 0.007$ & $0.10 \pm 0.011^{b}$ & $0.10 \pm 0.008^{b}$ & $0.092 \pm 0.013^{b}$ & $0.098 \pm 0.016^{b}$ & 0.003 \\
\hline Energy efficiency & $0.03 \pm 0.003^{b}$ & $0.05 \pm 0.005^{b}$ & $0.05 \pm 0.004^{b}$ & $0.04 \pm 0.006^{\mathrm{a}, \mathrm{b}, \mathrm{c}}$ & $0.04 \pm 0.007^{\mathrm{a}, \mathrm{b}, \mathrm{c}}$ & 0.001 \\
\hline
\end{tabular}

\footnotetext{
${ }^{\text {a }}$ The effect of the intervention was statistically significant $(\mathrm{p}<0.05)$ Compared to the control group (High-fat diet)

${ }^{b}$ The significant difference ( $\mathbf{p}<0.05$ ) was seen in comparison with the control group (Standard diet)

${ }^{c}$ This group showed a significant difference $(p<0.05)$ compared to Vitamin $D \&$ High-fat diet group
}

There was a significant difference between the Feed efficiency value of the groups in the fourth $(\mathrm{p}=0.003)$ and third $(\mathrm{p}=0.007)$ stages. In addition, there were significant differences in all four stages $(p<0.05)$ except for the second group $(p=0.52)$. However, no significant difference was found between the 3rd, 4th and 5th groups in the third stage compared to the second stage $(\mathrm{p}>0.05)$ (table $3)$.
There were also significant differences between the Energy efficiency value of the groups in the fourth $(\mathrm{p}=0.003)$ and third $(\mathrm{p}=0.007)$ stages. In addition, there was a significant difference between groups 1,3 and $5(\mathrm{p}=0.001)$ whereas there was no such difference between the means of group $2(0.52)$ and 4 (0.24). In addition, in the third stage, there was no significant difference between group 3 and 5 compared to the second stage $(\mathrm{p}>0.05)$ (table 3$)$. 
TABLE 3- Comparison between and within groups

\begin{tabular}{|c|c|c|c|c|c|}
\hline & Step 1 & Step 2 & Step 3 & Step 4 & P.value \\
\hline \multicolumn{6}{|l|}{ weight } \\
\hline Group- 1 & $134.64 \pm 22.74$ & $352.63 \pm 22.88$ & $370.96 \pm 16.86$ & $386.05 \pm 15.36^{\mathrm{a}}$ & $<0.001$ \\
\hline Group- 2 & $133.33 \pm 23.34$ & $336.72 \pm 34.96$ & $377.01 \pm 33.44$ & $438.55 \pm 25.34^{\mathrm{a}}$ & 0.002 \\
\hline Group- 3 & $131.78 \pm 25.69$ & $355.98 \pm 26.17$ & $388.61 \pm 27.51$ & 411. $87 \pm 17.67^{\mathrm{a}}$ & $<0.001$ \\
\hline Group- 4 & $128.79 \pm 27.46$ & $329.59 \pm 35.43$ & $384.61 \pm 22.28^{b}$ & 391.15 \pm 23.97 & $<0.001$ \\
\hline Group- 5 & $120.09 \pm 19.15$ & $312.48 \pm 32.71^{\mathrm{d}}$ & $324.66 \pm 33.79^{d}$ & $351.19 \pm 26.65^{e, f}$ & $<0.001$ \\
\hline P.value & 0.98 & 0.28 & 0.06 & 0.04 & \\
\hline \multicolumn{6}{|l|}{ BMI } \\
\hline Group- 1 & $0.41 \pm 0.08$ & $0.71 \pm 0.04$ & $0.71 \pm 0.05^{b}$ & $0.68 \pm 0.04^{\mathrm{a}}$ & $<0.001$ \\
\hline Group- 2 & $0.41 \pm 0.17$ & $0.66 \pm 0.04$ & $0.73 \pm 0.02$ & $0.78 \pm 0.04^{b, d}$ & 0.03 \\
\hline Group- 3 & $0.39 \pm 0.03$ & $0.72 \pm 0.01$ & $0.75 \pm 0.01$ & $0.80 \pm 0.02^{\mathrm{d}}$ & $<0.001$ \\
\hline Group- 4 & $0.37 \pm 0.10$ & $0.75 \pm \mathbf{0 . 0 7}$ & $0.69 \pm 0.08^{b}$ & $0.72 \pm 0.05^{b}$ & $<0.001$ \\
\hline Group- 5 & $0.43 \pm 0.08$ & $0.71 \pm \mathbf{0 . 0 7}$ & $0.64 \pm 0.05^{, e}$ & $0.67 \pm 0.05^{\text {a, b,e, f, g }}$ & $<0.001$ \\
\hline P.value & 0.76 & 0.30 & 0.05 & $<0.001$ & \\
\hline \multicolumn{6}{|l|}{ Lee Index } \\
\hline Group- 1 & $0.28 \pm 0.01$ & $0.31 \pm 0.009$ & $0.31 \pm 0.01^{b}$ & $0.30 \pm 0.005^{b}$ & $<0.001$ \\
\hline Group- 2 & $0.28 \pm 0.03$ & $0.31 \pm 0.01^{\mathrm{c}}$ & $0.31 \pm 0.008^{c}$ & $0.32 \pm 0.01^{c, e}$ & $<0.001$ \\
\hline Group- 3 & $0.27 \pm 0.008$ & $0.32 \pm 0.002$ & $0.32 \pm 0.003^{b}$ & $0.32 \pm 0.005^{\mathrm{e}}$ & $<0.001$ \\
\hline Group- 4 & $0.27 \pm 0.021$ & $0.32 \pm 0.012^{\mathrm{d}, \mathrm{e}}$ & $0.31 \pm 0.012$ & $0.31 \pm 0.005^{\mathrm{a}, \mathrm{e}, \mathrm{f}}$ & $<0.001$ \\
\hline Group- 5 & $0.25 \pm 0.01$ & $0.32 \pm 0.01$ & $0.30 \pm 0.009^{f}$ & $0.30 \pm 0.009^{a, e, f}$ & $<0.001$ \\
\hline P.value & 0.16 & 0.02 & 0.14 & 0.001 & \\
\hline \multicolumn{6}{|c|}{ Feed efficiency } \\
\hline Group- 1 & - & $0.05 \pm 0.01$ & $0.009 \pm 0.009$ & $0.07 \pm 0.007$ & $<0.001$ \\
\hline Group- 2 & - & $0.71 \pm 0.03$ & $0.08 \pm 0.07^{\mathrm{d}}$ & $0.10 \pm 0.01^{d}$ & 0.52 \\
\hline Group- 3 & - & $0.05 \pm 0.007$ & $0.04 \pm 0.01$ b,e & $0.10 \pm 0.008^{d}$ & 0.001 \\
\hline Group- 4 & - & $0.03 \pm 0.06$ & $0.04 \pm 0.01^{b, d, e}$ & $0.09 \pm 0.01^{\mathrm{d}, \mathrm{f}}$ & 0.02 \\
\hline Group- 5 & - & $0.02 \pm 0.02$ & $0.02 \pm 0.01^{b, e}$ & $0.09 \pm 0.01^{\mathrm{d}}$ & $<0.001$ \\
\hline P.value & - & 0.38 & 0.007 & 0.003 & \\
\hline \multicolumn{6}{|c|}{ Energy efficiency } \\
\hline Group- 1 & - & $0.02 \pm 0.007$ & $0.004 \pm 0.004$ & $0.03 \pm 0.003$ & $<0.001$ \\
\hline Group- 2 & - & $0.03 \pm 0.01$ & $0.04 \pm 0.03$ & $0.05 \pm 0.005^{\mathrm{d}}$ & 0.52 \\
\hline Group- 3 & - & $0.02 \pm 0.003$ & $0.02 \pm 0.008^{b}$ & $0.05 \pm 0.004^{d}$ & 0.001 \\
\hline Group- 4 & - & $0.01 \pm 0.03$ & $0.02 \pm 0.006$ & $0.04 \pm 0.006^{\mathrm{d}, \mathrm{f}}$ & 0.24 \\
\hline Group- 5 & - & $0.01 \pm 0.01$ & $0.01 \pm 0.006^{\mathrm{b}}$ & $0.04 \pm 0.007^{d}$ & $<0.001$ \\
\hline P.value & & 0.38 & 0.007 & 0.003 & \\
\hline
\end{tabular}

${ }^{a}$ The mean difference was not significant compared to step 3

${ }^{b}$ The mean difference was not significant compared to step 2

${ }^{c}$ The mean difference was not significant compared to step 1

d significant difference $(p<0.05)$ was seen in comparison with the control group (Standard diet)

${ }^{\mathrm{e}}$ The effect of the intervention was statistically significant $(\mathbf{p}<0.05)$ Compared to the control group (High-fat diet)

${ }^{\mathrm{f}}$ This group showed a significant difference $(\mathbf{p}<0.05)$ compared to Vitamin $\mathrm{D} \&$ High-fat diet group

${ }^{\mathrm{g}}$ significant difference $(\mathbf{p}<\mathbf{0 . 0 5})$ was seen in comparison with the group-3 (Endurance Exercise) 


\section{DISCUSSION}

The results of the present study showed that the body weight gain in the high-fat diet groups non-significantly increased compared to standard diet group, whiles endurance training with vitamin D supplementation reversed high fat diet-induced weight gain and decreased BMI and LEE. Also, vitamin $\mathrm{D}$ and endurance training separately suppressed to some extent this effect.

These findings are in agreement with the study Haghshenas et al. which showed a decrease in weight gain after eight weeks of endurance training and high-fat diet in male Wistar rats (20). Elj NE et al. investigated the effect of 30 days of two different diets (high protein and high-fat diet) and exercise training on weight loss enhancement. Significant reductions in weight gain and in food intake were reported with training (21). In another study, high-fat diet/endurance exercise, high-fat diet/interval exercise, and high-fat diet/concurrent exercise reduced body weight and adiposity (17).

One of the risk factors for the development of obesity is physical inactivity and a sedentary lifestyle. It seems endurance training can increase fat oxidation and therefore, lower body weight in trained rats may be due to the modified body composition by reducing fat mass as a result of exercise training (22-24). Also, energy expenditure increases during the exercise and causes a negative energy balance (25).

The results of this study presented that weight gain relation to total food intake (feed efficiency) and total energy intake (energy efficiency) decreased compared to high-fat diet groups without endurance training. This proposed that this effect perhaps is due to the increase in energy expenditure caused by exercise.

In Chaolu and colleges' study that exercise suppressed weight gain resulted in a high-fat diet and visceral fat did not increase in the exercise groups. The high-fat diet diminished plasma adiponectin and nesfatin levels, but this decrease is suppressed by exercise (26). Rocha-Rodrigues, et al. analyzed the effect of physical exercise against high-fat diet-induced adipokine and ghrelin alterations. 8week endurance training program decreased plasma insulin and leptin levels in the high-fatdiet endurance training group (27).
Based on the results of previous studies; it seems vitamin D deficiency has a predominant role in the pathogenesis of a number of disorders, such as obesity $(28,29)$ and obesity is associated with vitamin D deficiency and also, vitamin $\mathrm{D}$ metabolism, storage, and action are changed by adiposity $(30,31)$. Kayaniyil et al. showed that 25-hydroxy vitamin $\mathrm{D}$ was inversely associated with abdominal adiposity (32). A meta-analysis study revealed a positive association between BMI and vitamin D deficiency among the 23 articles included (33). In other meta-analysis based on 15 articles was indicated that the prevalence of vitamin D deficiency was associated with obesity (34). Polymorphisms in vitamin $\mathrm{D}$ receptor (VDR) may be associated with obesity (35). Several experimental studies have proposed that vitamin $\mathrm{D}$ deficiency can induce greater adiposity by promoting parathyroid hormone levels and overflow of calcium into adipocytes, thereby increasing lipogenesis (36). Based on these results, oral vitamin D larger than usual doses may be able to modify weight gain in obese patients. The efficacy of vitamin $\mathrm{D}$ consumption on weight loss in obese or overweight persons has provided inconsistent results $(37,38)$. Vitamin D supplementation during weight loss in overweight/obese women did not increase weight loss (39).

Higher calcium and vitamin D intake increased thermogenesis, fat oxidation and food intake (38). Supplementation with $25 \mu \mathrm{g} /$ day vitamin D3 significantly decreased body fat mass, however, body weight and waist circumference did not change statistically significant. Data also shows that vitamin D can enhance lean body mass and inhibit the development of adipocytes (40). In vitro study in rats indicated that large doses of vitamin $\mathrm{D}_{2}$ result in an increase in energy expenditure due to the uncoupling of oxidative phosphorylation in adipose tissues (41).

In conclusion, as regards an increased prevalence in obesity, effective prevention strategies are needed to slow the current epidemic. Exercise as one of the first-line preventive treatment for obesity is a low-cost lifestyle intervention that increases fat oxidation and can prevent obesity-associated pathologies (17). On the other hand, as respects obesity and vitamin D deficiency have 
concomitantly reached epidemic levels worldwide, the existence of a relationship between vitamin $\mathrm{D}$ status and BMI has been proposed (42).

\section{CONCLUSION}

Our findings suggest that endurance training and vitamin D supplementation may synergistically change weight gain due to high-fat diets; however, further studies that investigate the effects vitamin $\mathrm{D}$ and exercise on metabolic, biochemical and anthropometric factors are needed for exact conclusions. The

\section{REFERENCES}

1. Shamseddeen H, Getty JZ, Hamdallah IN, Ali MR. Epidemiology and economic impact of obesity and type 2 diabetes. Surg Clin North Am. 2011; 91(6): 1163-72, vii. doi: 10.1016/j.suc.2011.08.001.

2. Slevin E, Truesdale Kennedy M, McConkey R, Livingstone B, Fleming P. Obesity and overweight in intellectual and non-intellectually disabled children. $\mathrm{J}$ Intellect Disabil Res. 2014; 58(3): 211-20. doi: 10.1111/j.1365-2788.2012.01615.x.

3. Talaei A, Mohamadi kelishadi M, Adgi Z. the effect of vitamin $D$ on insulin resistance in type II diabetic patients. Diabetol Metab Syndr. 2011; 14 (5): 79-84. doi: 10.1186/1758-5996-5-8. [persian]

4. Bian S, Gao Y, Zhang M, Wang X, Liu W, Zhang D, et al. Dietary nutrient intake and metabolic syndrome risk in Chinese adults: a case-control study. Nutr J. 2013; 12: 106. doi: 10.1186/1475-2891-12-106.

5. Brenner DR, Arora P, Garcia-Bailo B, Wolever TM, Morrison $\mathrm{H}$, El-Sohemy A, et al. Plasma vitamin D levels and risk of metabolic syndrome in Canadians. Clin Invest Med. 2011; 34(6):E377.

6. Mohammadian S, Mortezazadeh R, Zaeri H, Vakili MA. Relationship between 25-hydroxy vitamin-D and obesity in 2-7 years old children referred to a paediatric hospital in Iran. J Clin Diagn Res. 2014; 8(9): PC06-8. doi: 10.7860/JCDR/2014/8282.4810.

7. Shin JY, Xun P, Nakamura Y, He K. Egg consumption in relation to risk of cardiovascular disease and diabetes: a systematic review and meta-analysis. Am J Clin Nutr. 2013; 98(1): 146-59. doi: 10.3945/ajen.112.051318.

8. Swithers SE, Ogden SB, Davidson TL. Fat substitutes promote weight gain in rats consuming high-fat diets. Behav Neurosci. 2011; 125(4): 512-8. doi: 10.1037/a0024404.

9. Williams NH. Promoting physical activity in primary care. BMJ. 2011; 343: d6615. doi: 10.1136/bmj.d6615. 10. Bradley RL, Jeon JY, Liu FF, Maratos-Flier E. Voluntary exercise improves insulin sensitivity and adipose tissue inflammation in diet-induced obese mice. Am J Physiol Endocrinol Metab. 2008; 295(3): E586-94. doi: 10.1152/ajpendo.00309.2007.
Current study had some limitations including lack of measurement of vitamin D status at the start of the study and after supplementation, absence of investigation of the effect of vitamin D supplementation and endurance training on metabolic factors, non-matching groups in terms of calorie intake.

\section{ACKNOWLEDGMENT}

The authors are very grateful to Shahid Mirghani Research Institute in order to provide research facilities.

11. Huang P, Li S, Shao M, Qi Q, Zhao F, You J, et al. Calorie restriction and endurance exercise share potent anti-inflammatory function in adipose tissues in ameliorating diet-induced obesity and insulin resistance in mice. Nutr Metab (Lond). 2010; 7: 59. doi: 10.1186/1743-7075-7-59.

12. Lin S, Thomas TC, Storlien LH, Huang XF. Development of high fat diet-induced obesity and leptin resistance in C57Bl/6J mice. Int J Obes Relat Metab Disord. 2000; 24(5): 639-46.

13. Pierard M, Conotte S, Tassin A, Boutry S, Uzureau $\mathrm{P}$, Boudjeltia KZ, et al. A Interactions of exercise training and high-fat diet on adiponectin forms and muscle receptors in mice. Nutr Metab (Lond). 2016; 13: 75. doi: 10.1186/s12986-016-0138-2.

14. Ferrante AW Jr. Obesity-induced inflammation: a metabolic dialogue in the language of inflammation. $\mathrm{J}$ Intern Med. 2007; 262(4): 408-14.

15. Huang BW, Chiang MT, Yao HT, Chiang W. The effect of high-fat and high-fructose diets on glucose tolerance and plasma lipid and leptin levels in rats. Diabetes Obes Metab. 2004; 6(2): 120-6.

16. Fontana L, Meyer TE, Klein S, Holloszy JO. Longterm calorie restriction is highly effective in reducing the risk for atherosclerosis in humans. Proc Natl Acad Sci U S A. 2004; 101(17): 6659-63.

17. Shen Y, Xu X, Yue K, Xu G. Effect of different exercise protocols on metabolic profiles and fatty acid metabolism in skeletal muscle in high-fat diet-fed rats. Obesity. 2015; 23(5): 1000-1006.

18. Mirghani SJ, Peeri M, Yaghoobpour Yekani O, Zamani M, Feizolahi F, Nikbin S, et al. Role or Synergistic Interaction of Adenosine and Vitamin D3 Alongside High-Intensity Interval Training and Isocaloric Moderate Intensity Training on Metabolic Parameters: Protocol for an Experimental Study. JMIR Res Protoc. 2019; 8(1): e10753. doi: 10.2196/10753.

19. Pereira MG, Ferreira JC, Bueno CR Jr, Mattos KC, Rosa KT, Irigoyen MC, et al. Exercise training reduces cardiac angiotensin II levels and prevents cardiac dysfunction in a genetic model of sympathetic hyperactivity-induced heart failure in mice. Eur J Appl Physiol. 2009; 105(6): 843-50. doi: 10.1007/s00421-0080967-4. 
20. Haghshenas R, Jafari M, Ravasi A, Kordi M, Gilani $\mathrm{N}$, Shariatzadeh $\mathrm{M}$, et al. The effect of eight weeks endurance training and high-fat diet on appetiteregulating hormones in rat plasma. Iran J Basic Med Sci. 2014; 17(4): 237-43.

21. Elj NE, Lac G, Tabka Z, Gharbi N, Fezaa SE. Effect of Physical Exercise on Reducing Food Intake and Weight Gain. Procedia - Social and Behavioral Sciences. 2011; 30: 2027-31.

22. Mirghani SJ, Alinejad HA, Azarbayjani MA, Mazidi A, Mirghani SA. Influence of strength, endurance and concurrent training on the lipid profile and blood testosterone and cortisol response in young male wrestlers. Baltic Journal Of Health And Physical Activity. 2014; 6(1): 7-16. DOI: 10.2478/bjha-20140001.

23. Mirghani SJ, Yousefi MS. The effect of interval recovery periods during HIIT on liver enzymes and lipid profile in overweight women. Science \& Sports. 2015; 30: $147-154$

24. Mirghani SJ, Yousefi MS, Pekkala S, Sharifian S, Beyshami G. Shorter recovery time following highintensity interval training induced higher body fat loss among overweight women. Sport Sciences for Health. 2019; 15: 157-165.

25. Bi S, Scott KA, Hyun J, Ladenheim EE, Moran TH. Running wheel activity prevents hyperphagia and obesity in Otsuka long-evans Tokushima Fatty rats: role of hypothalamic signaling. Endocrinology. 2005;146(4):1676-85.

26. Chaolu H, Asakawa A, Ushikai M, Li YX, Cheng $\mathrm{KC}, \mathrm{Li} \mathrm{JB}$, et al. Effect of exercise and high-fat diet on plasma adiponectin and nesfatin levels in mice. Exp Ther Med. 2011; 2(2): 369-73.

27. Rocha-Rodrigues S, Goncalves IO, Beleza J, Ascensao A, Magalhaes J. Physical exercise mitigates high-fat diet-induced adiposopathy and related endocrine alterations in an animal model of obesity. $\mathrm{J}$ Physiol Biochem. 2018; 74(2): 235-246. doi: 10.1007/s13105-018-0609-1.

28. Florentin M, Elisaf MS, Mikhailidis DP, Liberopoulos EN. Vitamin D and metabolic syndrome: is there a link? Curr Pharm Des. 2010; 16(30): 3417-34.

29. Wimalawansa SJ. Associations of vitamin $D$ with insulin resistance, obesity, type 2 diabetes, and metabolic syndrome. J Steroid Biochem Mol Biol. 2018; 175: 177189. doi: 10.1016/j.jsbmb.2016.09.017.

30. Vimaleswaran KS, Berry DJ, Lu C, Tikkanen E, Pilz $\mathrm{S}$, Hiraki LT, et al. Causal relationship between obesity and vitamin $D$ status: bi-directional Mendelian randomization analysis of multiple cohorts. PLoS Med. 2013; 10(2): e1001383. doi: 10.1371/journal.pmed.1001383.

31. Ruiz-Ojeda FJ, Anguita-Ruiz A, Leis R, Aguilera CM. Genetic Factors and Molecular Mechanisms of Vitamin D and Obesity Relationship. Ann Nutr Metab. 2018; 73(2): 89-99. doi: 10.1159/000490669.
32. Kayaniyil S, Vieth R, Harris SB, Retnakaran R, Knight JA, Gerstein HC, et al. Association of $25(\mathrm{OH}) \mathrm{D}$ and PTH with metabolic syndrome and its traditional and nontraditional components. $\mathrm{J}$ Clin Endocrinol Metab. 2011; 96(1): 168-75. doi: 10.1210/jc.2010-1439.

33. Pereira-Santos M, Costa PR, Assis AM, Santos CA, Santos DB. Obesity and vitamin $D$ deficiency: $a$ systematic review and meta-analysis. Obes Rev. 2015; 16(4): 341-9. doi: 10.1111/obr.12239.

34. Yao Y, Zhu L, He L, Duan Y, Liang W, Nie Z, et al. A meta-analysis of the relationship between vitamin $D$ deficiency and obesity. Int J Clin Exp Med. 2015; 8(9): 14977-14984.

35. Wortsman J, Matsuoka LY, Chen TC, Lu Z, Holick MF. Decreased bioavailability of vitamin $D$ in obesity. Am J Clin Nutr. 2000; 72(3): 690-3.

36. Wong KE, Kong J, Zhang W, Szeto FL, Ye H, Deb $\mathrm{DK}$, et al. Targeted expression of human vitamin $D$ receptor in adipocytes decreases energy expenditure and induces obesity in mice. J Biol Chem. 2011; 286(39): 33804-10. doi: 10.1074/jbc.M111.257568.

37. Hjelmesaeth J, Hofso D, Aasheim ET, Jenssen T, Moan J, Hager $\mathrm{H}$, et al. Parathyroid hormone, but not vitamin $D$, is associated with the metabolic syndrome in morbidly obese women and men: a cross-sectional study. Cardiovasc Diabetol. 2009; 8: 7. doi: 10.1186/14752840-8-7.

38. Karefylakis C, Sarnblad S, Ariander A, Ehlersson G, Rask E, Rask P. Effect of Vitamin D supplementation on body composition and cardiorespiratory fitness in overweight men-a randomized controlled trial. Endocrine. 2018; 61(3): 388-397. doi: 10.1007/s12020018-1665-6.

39. Ping-Delfos WC, Soares M. Diet induced thermogenesis, fat oxidation and food intake following sequential meals: influence of calcium and vitamin $D$. Clin Nutr. 2011; 30(3): 376-83. doi: 10.1016/j.clnu.2010.11.006.

40. Mason C, Xiao L, Imayama I, Duggan C, Wang CY, Korde L, et al. Vitamin D3 supplementation during weight loss: a double-blind randomized controlled trial. Am J Clin Nutr. 2014; 99(5): 1015-25. doi: 10.3945/ajen.113.073734.

41. Zittermann A, Frisch S, Berthold HK, Gotting C, Kuhn J, Kleesiek K, et al. Vitamin D supplementation enhances the beneficial effects of weight loss on cardiovascular disease risk markers. Am J Clin Nutr. 2009 May;89(5):1321-7. doi: 10.3945/ajen.2008.27004.

42. Fassina G, Maragno I, Dorigo P, Contessa AR. Effect of vitamin D2 on hormone-stimulated lipolysis in vitro. Eur J Pharmacol. 1969; 5(3): 286-90.

43. Pourshahidi LK. Vitamin D and obesity: current perspectives and future directions. Proc Nutr Soc. 2015; 74(2): 115-24. doi: 10.1017/S0029665114001578. 